\title{
Use of Large Clear-Cuts by Wilson's Warbler in an Eastern Canadian Boreal Forest
}

\section{Utilisation de vastes parterres de coupe totale par la Paruline à calotte noire dans une forêt boréale de l'Est du Canada}

\author{
André Desrochers ${ }^{1}$, Jacinthe Tardif ${ }^{1}$, and Marc J. Mazerolle ${ }^{2}$
}

\begin{abstract}
Wilson's Warbler (Cardellina pusilla; WIWA) has been declining for several decades, possibly because of habitat loss. We compared occupancy of territorial males in two habitat types of Québec's boreal forest, alder (Alnus spp.) scrubland and recent clear-cuts. Singing males occurred in clusters, their occupancy was similar in both habitats, but increased with the amount of alder or clear-cut within $400 \mathrm{~m}$ of point-count stations. A despotic distribution of males between habitats appeared unlikely, because there were no differences in morphology between males captured in clear-cuts vs. alder. Those results contrast with the prevailing view, mostly based on western populations, that WIWA are wetland or riparian specialists, and provide the first evidence for a preference for large tracts of habitat in this species. Clear-cuts in the boreal forest may benefit WIWA by supplying alternative nesting habitat. However, the role of clear-cuts as source or sink habitats needs to be addressed with data on reproduction.
\end{abstract}

RÉSUMÉ. Les populations de Paruline à calotte noire (Cardellina pusilla; PACN) sont en déclin depuis plusieurs décennies, peut-être en raison de la perte d'habitat. Nous avons comparé le taux d'occupation par des mâles territoriaux dans deux types de milieux de la forêt boréale québécoise, des aulnaies (Alnus spp.) et des coupes totales récentes. Nos résultats indiquent que les mâles chanteurs étaient groupés; le taux d'occupation était similaire dans les deux milieux et augmentait avec la quantité d'aulnes ou de coupes totales présente dans le rayon de $400 \mathrm{~m}$ des stations d'écoute. Une distribution despotique des mâles selon les milieux s'est avérée peu probable, parce que la morphologie des mâles capturés dans les aulnaies ne différait pas de celle des mâles capturés dans les coupes totales. Ces résultats ne concordent pas avec les connaissances générales actuelles principalement fondées sur les populations de l'Ouest -voulant que la PACN soit une spécialiste des milieux humides ou ripariens, et fournissent les premières observations d'une préférence pour de vastes parterres d'habitat chez cette espèce. Les coupes totales en forêt boréale représentent peut-être une alternative comme habitat de nidification pour la PACN. Toutefois, le rôle des coupes totales, à savoir si elles représentent un habitat propice ou une trappe écologique, doit être étudié à l'aide de données sur la reproduction.

Key Words: area-sensitivity; Cardellina pusilla; forest management; forest succession; generalized linear mixed model; habitat use; morphology; occupancy modeling; patch size; Quebec; wetlands; Wilson's Warbler

\section{INTRODUCTION}

Numbers of Wilson's Warbler (Cardellina pusilla; WIWA) reported on breeding grounds have been declining by $2.1 \%$ annually since 1966 (Sauer et al. 2011). To date, no study has offered explanations for this decline. It is therefore not possible to determine whether this migrant bird's decline is mainly due to phenomena occurring on breeding grounds, wintering grounds, migration routes, or a combination of them. Studies on the breeding ecology of WIWA focused mostly on the two western subspecies (C. pusilla pileolata, $C$. p. chryseola; Ammon and Gilbert 1999). The eastern subspecies C. $p$.

${ }^{1}$ Centre d'étude de la forêt, Université Laval, Canada, ${ }^{2}$ Centre d'étude de la forêt, Université du Québec en Abitibi-Témiscamingue pusilla appears less abundant than the western one, based on haplotype frequencies in wintering sites (Kimura et al. 2002). It is well separated phylogenetically and perhaps ecologically from the western subspecies (Clegg et al. 2003), but its breeding biology remains largely unknown (Ammon and Gilbert 1999).

Are large-scale habitat alterations in the boreal a cause for concern for WIWA? In its North American breeding grounds, WIWA occur mostly in wet scrublands, often surrounded by coniferous woodland (Ammon and Gilbert 1999). Scrubland habitat is in decline in the eastern United States (Brooks 2003,

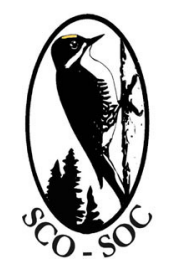

Sponsored by the Society of Canadian Ornithologists and Bird Studies Canada Parrainée par la Société des ornithologistes du Canada et Études d'oiseaux Canada

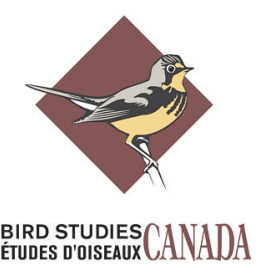


Schlossberg and King 2009), but the areas concerned are mostly south of the species' breeding range. Extensive logging of boreal mature forests (Boucher et al. 2009) has promoted habitats with a patchy structure similar to that found in alder (Alnus spp.) and other wet scrubland. Additionally, the water table can move up in the five years following clear-cutting (Pothier et al. 2003), creating favorable mesic conditions. WIWA have been reported as breeding in recent clear-cuts in Québec and Labrador (Crête et al. 1995, Imbeau et al. 1999, Simon et al. 2002). Clear-cuts may be suboptimal for the species, however. In such a case, we would expect a despotic distribution of WIWA (sensu Fretwell 1972) in favor of alder scrubland, with individuals occupying alder scrubland exhibiting a greater resource-holding potential, as determined by age or morphology (Kölliker et al. 1999), than those occupying clear-cuts.

As with other songbirds, responses of WIWA to changes in habitat area will be exacerbated if they exhibit area-sensitivity, i.e., a preference of large tracts of habitats to small ones (Desrochers et al. 2010), or if they occur in clusters within suitable habitat (Ahlering and Faaborg 2006). In fact, territory clustering may be one of the main causes of area-sensitivity (Bourque and Desrochers 2006), and could be a proximate mechanism leading to precipitous declines in species' occupancy following habitat loss. However, no published studies have reported area-sensitivity, clustering, or the lack thereof, in WIWA.

Our objective was to compare the use of alder scrubland and clear-cut habitats of an eastern Canadian forest by territorial WIWA. Additionally, we sought evidence for a despotic distribution between habitats by comparing the age class and morphology of males caught in alder scrubland and clear-cuts. Finally, we evaluated habitat area-sensitivity and clustering in the distribution of singing WIWA males, independent of habitat type.

\section{METHODS}

\section{Study area}

The study was conducted in the Forêt Montmorency, a $66 \mathrm{~km}^{2}$ area of managed boreal landscape $60 \mathrm{~km}$ north of Québec City, Canada (Fig. 1). Mean temperatures in June, July, and August are $12.3^{\circ} \mathrm{C}, 14.6^{\circ} \mathrm{C}$, and $13.5^{\circ} \mathrm{C}$, respectively. Mean annual precipitation is $1416.5 \mathrm{~mm}, 951.2 \mathrm{~mm}$ of which falls as rain and $465.3 \mathrm{~mm}$ as the water equivalent of snow (data from an automated weather station at the study area, operated by Environment Canada). The landscape is hilly with elevations ranging from 600 to $1100 \mathrm{~m}$. Balsam fir (Abies balsamea) dominates mature forest stands accompanied by black spruce (Picea mariana), white birch (Betula papyrifera), and white spruce (P. glauca; Beauchesne et al. 1991). Forêt Montmorency has been managed for timber for more than 70 years, mostly by clear-cuts. Thus, it has become a fragmented forest with stands of differing ages and sizes ranging from 1 to 100 ha.

Fig. 1. Forót Montmorency and locations of alder (Alnus spp.) and clear-cut $(<15 \mathrm{y})$ patches and point-count sites. Forót Montmorency is located $60 \mathrm{~km}$ north of Québec city, Canada.

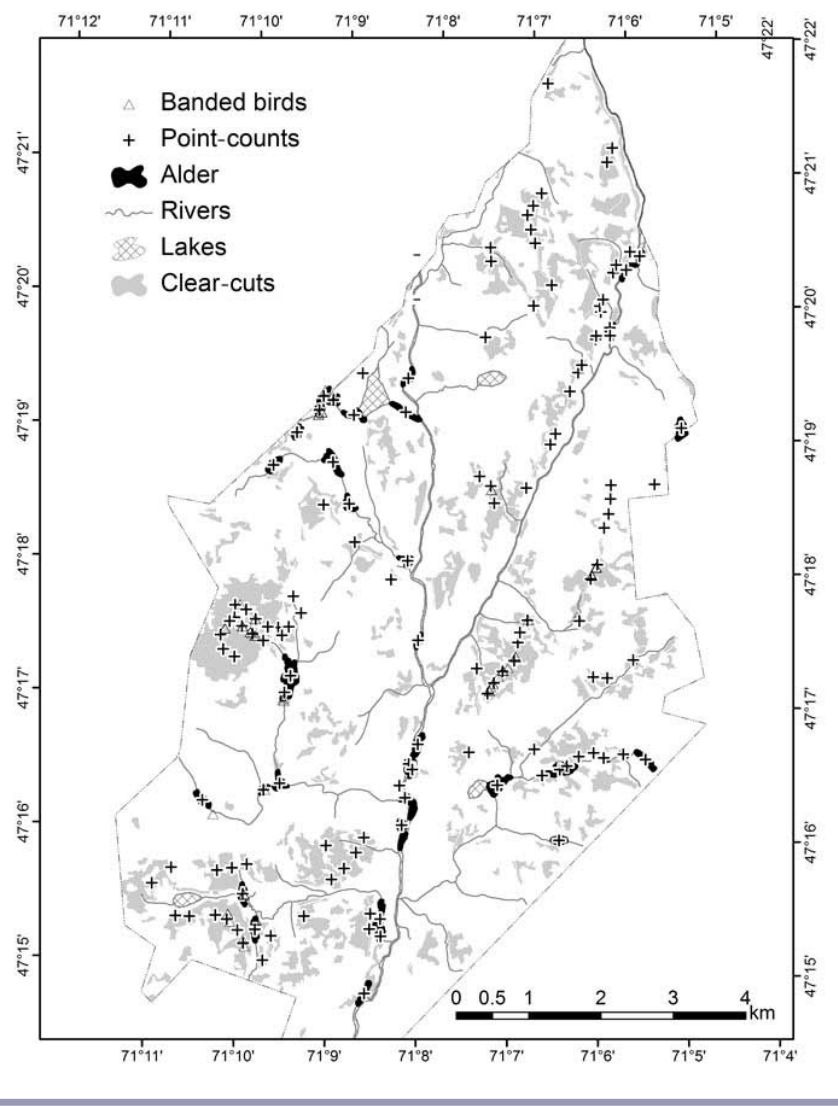

\section{Point-counts}

All known alder (Alnus rugosa) scrublands, ranging in size from 0.2 to 4.8 ha, in the study area and most recent clear-cuts ( $<15$ years) were sampled. We obtained current locations and details of habitats from a Geographic Information System (GIS) based on the interpretation of aerial photos 1:10,000 ground-truthed with 201 sample plots randomly placed on the study area in 2002. Clear-cut sites experienced natural regeneration, mostly by balsam fir, white birch, white spruce, fruit shrubs (Rubus spp., Sambucus spp.), and alder (de Bellefeuille et al. 2001). Point-count stations were established along logging roads that crossed clear-cuts $(n=97)$ and in the coordinate centroid of naturally occurring alder scrublands also adjoining roads ( $n=39$; Fig. 1 ). All point-count stations were separated by a minimum distance of $200 \mathrm{~m}$ (mean nearest neighbor distance $=274 \mathrm{~m}$ ) and we assume that individual birds were not counted in different point-count stations. We 
Table 1. Comparison of multiseason models for habitat occupancy and detection probability of Wilson's Warbler (Cardellina pusilla), based on 136 point-count stations at Forêt Montmorency, Québec, 2003-2004. Area of habitat (clear-cut or alder, Alnus spp.) was calculated within $400 \mathrm{~m}$ of point-count stations, Alder $=$ alder scrubland (vs. clear-cut as reference habitat), $\gamma=$ probability of colonization, $\psi=$ occupancy, $\varepsilon=$ probability of extinction, $\mathrm{p}()=$. fixed probability of detection, $\mathrm{p}(\mathrm{visit})=\mathrm{visit}-$ and year-specific probability of detection.

\begin{tabular}{|c|c|c|c|c|}
\hline Model & $K$ & $A I C_{c}$ & $\Delta_{i}$ & $w_{i}$ \\
\hline$\psi_{2003}($ Area of habitat $), \gamma(),. \varepsilon(),$.$p (visit)$ & 9 & 642.07 & 0 & 0.56 \\
\hline$\psi_{2003}($ Area of habitat + Alder $), \gamma(),. \varepsilon(),. p($ visit $)$ & 10 & 643.21 & 1.14 & 0.32 \\
\hline$\psi_{2003}(),. \gamma(),. \varepsilon(),. p($ visit $)$ & 8 & 645.04 & 2.96 & 0.13 \\
\hline$\psi_{2003}($ Area of habitat), $\gamma(),. \varepsilon(),. p()$. & 5 & 662.04 & 19.97 & 0 \\
\hline$\psi_{2003}($ Area of habitat + Alder $), \gamma(),. \varepsilon(),. p()$. & 6 & 663.53 & 21.46 & 0 \\
\hline$\Psi_{2003}(),. \gamma(),. \varepsilon(),. p()$. & 4 & 665.24 & 23.17 & 0 \\
\hline
\end{tabular}

measured the area of clear-cut or alder scrublands within 400 $\mathrm{m}$ of the center of each point-count with ArcGIS 9.3 (ESRI 2008) to assess the ecological context of WIWA territories. Landscape overlap among neighboring point-count stations did not violate statistical independence (Zuckerberg et al. 2012). Songbirds may respond to landscape composition at greater radii (Desrochers et al. 2010) but the proximity of sampling points prevented analysis at larger radii, because it would have reduced the variation of regressors among plots, statistical power, and scope of inferences. We repeated all statistical analyses with radii of $100 \mathrm{~m}$ and $200 \mathrm{~m}$, and came to similar results, thus for brevity we only show the results with $400 \mathrm{~m}$ radius.

Each point-count station was sampled three times during the 2003 breeding season (27 May - 21 July) and twice in 2004 (19 May - 13 June). Sampling order was randomized with respect to habitat type and area, to avoid possible bias due to plant phenology. Six different observers well trained with WIWA vocalizations, were rotated across sites so each observer made no more than one visit per point-count station in a given year. Point-counts were conducted from 0400 to 1000 EST on days without precipitation or strong winds. They consisted of 5 min of passive observation followed by 5 min of WIWA song played at a volume comparable to that of bird vocalizations. Presence was recorded every time a WIWA was detected within $50 \mathrm{~m}$ of the observer.

\section{Occupancy and detection probability}

We conducted multiseason site occupancy analyses (MacKenzie et al. 2003, 2006). Models were fit by maximum likelihood with the unmarked package 0.9-0 in $\mathrm{R}$ Version 2.13.0 (Ihaka and Gentleman 1996, Fiske et al. 2011). We compared six models to evaluate WIWA occupancy in response to habitat type and size (Table 1). No goodness-offit (GOF) test is currently available for multiseason models. As a surrogate, we computed GOF tests for single season models with time-dependent detection probability and models including the parameters of interest on occupancy with a parametric bootstrap approach (MacKenzie and Bailey 2004,
Hines 2006) and 10,000 iterations of the most general models to estimate c-hat (Burnham and Anderson 2002). Single season models fit the data well (c-hat ranged from 1 to 1.256). Numeric variables were centered on their mean before analyses. We used a model selection and multimodel inference approach (Burnham and Anderson 2002), based on the AICc implemented in the AICcmodavg package (Mazerolle 2011). To address effects of clear-cut age on WIWA occupancy, we analyzed clear-cut sites as a subset and compared six candidate models (Table 2).

Occupancy modeling has limitations here because habitat patches in boreal forests may contain few or single WIWA pairs, and individual males may frequently foray outside their territory (reviewed by Whitaker and Warkentin 2010), undermining the assumption of closure of the occupancy state required by occupancy models (MacKenzie et al. 2003). To complement occupancy models, we estimated habitat use by WIWA with generalized linear mixed models assuming perfect detection, but no closure of occupancy state. We used detection of singing males within $50 \mathrm{~m}$ as a binomial response to habitat type, age, and habitat area (clear-cut or alder) within $400 \mathrm{~m}$ as fixed effects. We included year and site as random effects. We used the Kenward-Roger method for the estimation of residual degrees of freedom (Schaalje et al. 2001). We accounted for spatial structure in mixed-model residuals by using a spatially corrected residual covariance matrix with exponential distance weighting (proc GLIMMIX, SAS Institute 2009). Occupancy modeling under maximum likelihood estimation does not allow for incorporation of spatially corrected covariance matrices among study sites, except where spatial replication substitutes actual temporal visits to sites (Hines et al. 2010).

\section{Clusters of singing males}

We tested whether singing WIWA males occurred in clusters, randomly, or in regular arrays, independent of habitat type or size, based on the spatial autocorrelation (procedure VARIOGRAM, SAS Institute 2009) of standardized deviance residuals. Those residuals were obtained from a generalized 
Table 2. Multiseason occupancy of clear-cuts $(\mathrm{n}=97)$ by Wilson's Warbler (Cardellina pusilla), as a function of clear-cut age and area at Forêt Montmorency, Québec, 2003-2004. Age = age years since clear-cut. Area of habitat (clear-cut or alder, Alnus spp.) was calculated within $400 \mathrm{~m}$ of point-count stations. See Table 1 legend for other symbol definitions.

\begin{tabular}{|c|c|c|c|c|}
\hline Model & $K$ & $A I C_{c}$ & $\Delta_{i}$ & $w_{j}$ \\
\hline$\psi_{2003}($ Area of habitat + Age $), \gamma(),. \varepsilon=(),$.$p (visit)$ & 10 & 511.80 & 0 & 0.92 \\
\hline$\psi_{2003}($ Area of habitat $), \gamma(),. \varepsilon=(),$.$p (visit)$ & 9 & 516.93 & 5.13 & 0.07 \\
\hline$\psi_{2003}(),. \gamma(),. \varepsilon=(),. p($ visit $)$ & 8 & 520.64 & 8.84 & 0.01 \\
\hline$\psi_{2003}($ Area of habitat + Age $), \gamma(),. \varepsilon=(),. p()$. & 6 & 523.32 & 11.52 & 0 \\
\hline$\psi_{2003}($ Area of habitat $), \gamma(),. \varepsilon=(),. p()$. & 5 & 528.60 & 16.80 & 0 \\
\hline$\Psi_{2003}(),. \gamma(),. \varepsilon=(),. p()$. & 4 & 532.13 & 20.33 & 0 \\
\hline
\end{tabular}

linear model with detection of singing males as a binomial response (procedure GLIMMIX, SAS Institute 2009), habitat type and area within $400 \mathrm{~m}$ as fixed effects, and year and site number as random effects. We used Moran's I as a measure of spatial autocorrelation.

\section{Morphology and age}

Between 28 May and 14 July 2003 and 2004, we captured 52 males in alder and clear-cut sites, by attracting them to mist nests with song playbacks. Each individual captured was color-banded and gender was assigned, based on the presence of a cloacal protuberance or a brood patch. Age class (second year or after second year) was determined from flight feather wear and shape (Pyle 1997). We measured body mass, wing length (flattened), outer rectrix length (2003 only), exposed culmen, and took a digital photograph of the top of the head. The length of each individual's black cap on the crown was measured with Adobe Photoshop ${ }^{\circledR}$ with a correction for scale based on the exposed culmen length measured in the field and visible in the pictures. The length of the black cap was assumed to be indicative of phenotypic quality for males (Rohwer 1975, Thusius et al. 2001). Captures were attempted in every site where WIWA had been detected previously at least once. Capture sites were dispersed over the entire study area (Fig. 1). We performed independent-sample $t$-tests on the five measurements taken to compare morphological traits between individuals from both sites. Residuals met normality and homoscedasticity assumptions.

\section{RESULTS}

\section{Relative use of alder and clear-cut patches}

Territorial male WIWA $(n=52)$ were detected in $34 \%$ of the 39 alder sites and $40 \%$ of the 97 clear-cut sites. Detection probability of singing males varied among visits (Table 1; compare models with $p$ (visit) vs. models with $p()$.$) . WIWA$ occupancy estimates were similar in alder and clear-cut patches (model-averaged beta estimate $=1.65,95 \%$ CI [ -2.07 , 5.37]; data from 2003 only). Mixed models also indicated similar use of alder and clear-cut patches (beta estimate $=0.55$, $95 \%$ CI [-0.02, 1.13]; data from 2003-2004).
Fig. 2. Occupancy of Wilson's Warbler (Cardellina pusilla) in clear-cuts and alder (Alnus spp.) patches of different sizes in 2003. Model-averaged estimates based on multiseason occupancy models for alder and clear-cut combined. (a) Influence of habitat type (clear-cut or alder) and area within a radius of $400 \mathrm{~m}$ on occupancy probability of Wilson's Warbler during 2003 (model-averaged $\psi$ ). Raw proportions of detections are provided for comparison: triangles denote clearcut sites, circles denote alder sites. (b) Changes in detection probability between point-count visits.
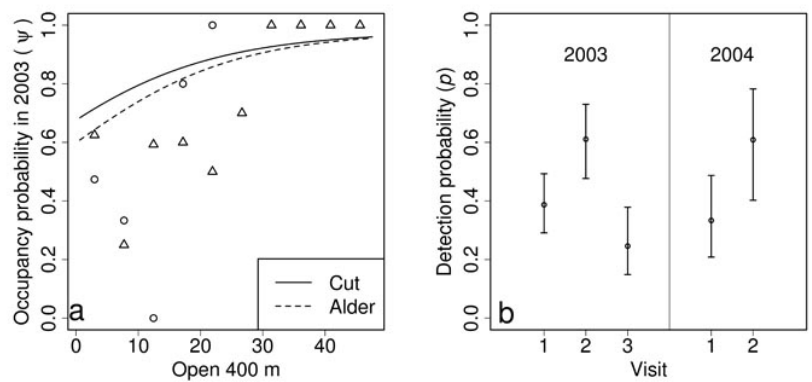

\section{Clear-cut area, clear-cut age, and clusters of singing males}

WIWA occupancy estimates in 2003 tended to be higher in large clear-cuts or alder patches (model-averaged beta estimate $=0.07,95 \%$ CI $[0.00,0.15]$; Fig. 2). The discrepancy between raw proportions of detections and occupancy model estimates in Figure 2a may be due to large variation in detection or movement patterns of WIWA depending on clearcut type and area. The model including clear-cut age and area (alder patches excluded because "age since clear-cut" is not applicable there) performed best (Table 2), but modelaveraged estimates overlapped zero for clear-cut area (beta estimate $=0.04,95 \%$ CI $[-0.07,0.15]$ ), and clear-cut age (beta estimate $=0.39,95 \%$ CI $[-0.09,0.87])$. According to the mixed-model approach, WIWA detections were also more frequent in larger habitat patches (clear-cuts or alder; beta 
Table 3. Morphology of male Wilson's Warblers (Cardellina pusilla) in alder (Alnus spp.) and clear-cut habitats at Forêt Montmorency, Québec, 2003-2004. Outer rectrix length is the mean of the two outer rectrices. Data from 2003 only.

\begin{tabular}{|c|c|c|c|c|c|c|c|c|}
\hline \multirow[t]{2}{*}{ Measurement } & \multicolumn{3}{|c|}{ Alder } & \multicolumn{3}{|c|}{ Clear-cut } & \multirow[t]{2}{*}{$t$} & \multirow[t]{2}{*}{$P$} \\
\hline & Mean & $\mathrm{SD}$ & $n$ & Mean & $\mathrm{SD}$ & $n$ & & \\
\hline Body mass (g) & 7.30 & 0.12 & 21 & 7.25 & 0.10 & 43 & 0.35 & 0.7 \\
\hline Cap length (mm) & 14.11 & 0.73 & 14 & 14.61 & 0.43 & 33 & -0.62 & 0.5 \\
\hline Cap width (mm) & 13.62 & 0.62 & 14 & 13.59 & 0.32 & 33 & 0.04 & 0.9 \\
\hline Culmen length (mm) & 7.92 & 0.09 & 18 & 8.15 & 0.07 & 44 & -1.81 & 0.08 \\
\hline Mean rectrix length (mm) & 50.20 & 0.31 & 16 & $\mathbf{5 0 . 8 0}$ & 0.34 & 27 & -1.19 & 0.2 \\
\hline Wing length (mm) & 54.88 & 0.31 & 21 & 54.43 & 0.28 & 45 & 0.98 & 0.3 \\
\hline
\end{tabular}

estimate $=0.05,95 \% \mathrm{CI}[0.03,0.07])$. When only clear-cuts were analyzed, mixed-models showed that WIWA detections were more frequent in larger clear-cuts (beta estimate $=0.04$, $95 \%$ CI $[0.02,0.06])$, and older clear-cuts (beta estimate $=$ $0.12,95 \%$ CI $[0.06,0.18])$. Mixed-model residuals for WIWA detection after accounting for habitat type and area were spatially autocorrelated (Fig. 3), particularly at distance lags between 300 and $400 \mathrm{~m}$, indicating that singing WIWA males were spatially clustered independent of the area of habitat around point-count stations.

\section{Morphology and age}

We found no evidence that males occurring in alder sites differed morphologically from those occurring in clear-cuts (Table 3). Thirty-eight percent (5/13) of males caught and aged reliably in alder scrublands were juveniles, born in the previous year. Fifty-two percent (14/27) of males caught and aged reliably in clear-cuts were juveniles. The difference between the two age ratios was not significant $\left(\mathrm{c}^{2}=0.63 \mathrm{df}\right.$ $=1, P=0.4$ ).

\section{DISCUSSION}

The frequent use of clear-cuts by WIWA contrasts with previous studies suggesting that the species nests in wet scrublands, often surrounded by coniferous woodland (Gauthier and Aubry 1996, Ammon and Gilbert 1999). Several alder sites with apparently suitable vegetation structure were unused, suggesting that saturation of alder habitat was not a likely cause for the use of clear-cuts. One possible reason for regular occurrence of WIWA in clear-cuts is that alders sometimes colonize clear-cuts. Alders were present in 20\% of the clear-cuts where WIWA were present (A. Desrochers, unpublished data). Thus, alders contributed to the patchy vegetation structure generally found in extensive clear-cuts of the eastern Canadian boreal forest (Courteau 2000, Boucher et al. 2009). In addition to alder patches, recent clear-cuts in the study region are often characterized by mesic soil conditions because of a rise in the water table after clearcutting (Pothier et al. 2003), which may further improve nesting habitat and nest site quality for WIWA, a ground or near-ground nester (Ammon and Gilbert 1999). The extensive
Fig. 3. Spatial autocorrelation of deviance residuals from a generalized mixed model of Wilson's Warbler (Cardellina pusilla) occurrence at Forêt Montmorency, Québec. Warbler detection was treated as a binomial response, with habitat type and area within $400 \mathrm{~m}$ as fixed effects, and site and year as random effects. Triangles denote Moran's I values significantly greater than zero.

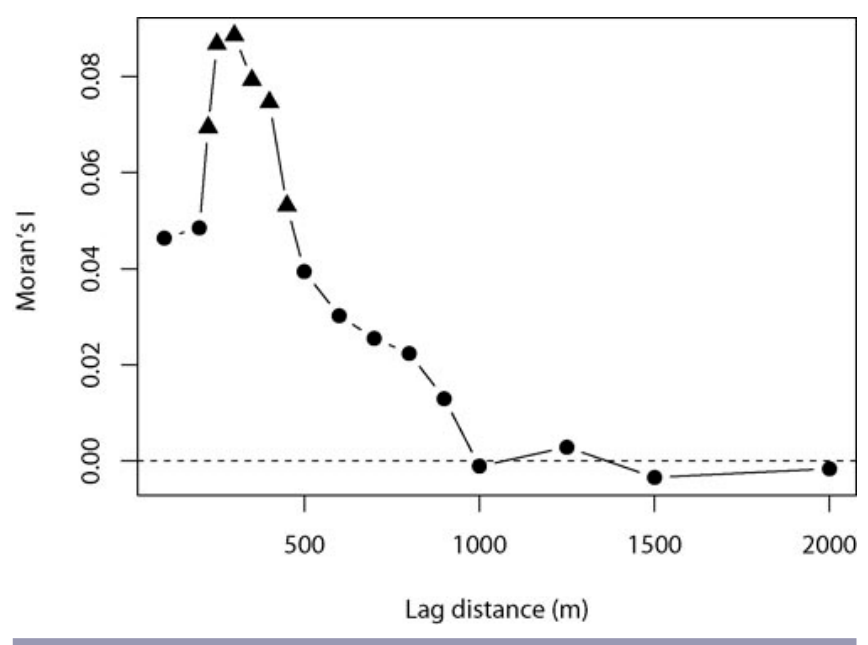

use of clear-cuts and other nonriparian habitats may be restricted to the eastern subspecies (C. p. pusilla), but habitat use should be investigated at a broader geographic portion of the species' range to support this hypothesis. In their review of the effects of silvicultural treatments in the Rockies, Hejl et al. (1995) reported 13 bird species exhibiting a preference for recent $(<10$-y-old $)$ clear-cuts vs. older forest stands. However, WIWA appeared to avoid recent clear-cuts in the region surveyed; they were associated with regenerating (10-20-y-old) stands (Hejl et al. 1995).

Studies on territorial migrant bird species report that older individuals tend to take the most suitable territories first, relegating other individuals to alternative sites of lesser potential (Kokko 1999). Data on habitat-specific reproductive 
success combined with population density are best suited to assess territory quality (Fretwell 1972, Morris 1989). However, morphological traits are often good indicators of resource-holding potential, and sometimes, fitness, even for socially monogamous species (Kölliker et al. 1999). For example, in another parulid species, the Common Yellowthroat (Geothlypis trichas), the size of the males' black mask is correlated with their mating success (Thusius et al. 2001). Based on age ratios, body measurements, and black cap size, we have no indication that the resource-holding potential was different between males of alder and clear-cut habitats, contrary to the expectation from an ideal despotic distribution of WIWA territories. However, data on reproduction is needed to come to a reliable conclusion about the relative quality of clear-cut and alder habitats. For now, we can only speculate that the extensive use of clear-cuts by WIWA favors them by providing additional, although transient, habitat, as is the case for other songbirds (Hunter et al. 2001). Consistently with this hypothesis, Drapeau et al. (2000) reported a greater occurrence of WIWA in industrial (vs. unmanaged) forests of Abitibi, Québec.

In addition to often establishing their territories in clear-cuts, WIWA tended to be associated with large, open areas consisting mostly of clear-cuts and alders. Area sensitivity has been reported for the species, but only in its wintering range, where WIWA appear to prefer large, closed, mature forests, i.e., its local wintering habitat, to small ones (Graham and Blake 2001). To our knowledge, this is the first evidence of area sensitivity for breeding WIWA, adding this species to an already long list of area-sensitive songbirds in eastern North America (e.g., 32 of 35 species investigated in Desrochers et al. 2010). Thus, WIWA not only respond favorably to clearcuts, but may even benefit from larger clear-cut areas, at least up to 100 ha. Larger patches of habitat may benefit WIWA by providing opportunities for the establishment of territory clusters (Bourque and Desrochers 2006) and facilitating the exchange of 'public information,' i.e., information about nesting success available to neighbors (Nocera et al. 2009 and references therein). Indeed, WIWA occurrence was strongly clustered, independent of habitat type and size. Furthermore, the spatial scale at which spatial autocorrelation was highest corresponds to the size of territorial neighborhoods, given the reported territory size for this species (range $0.06-2.0$ ha; Ammon and Gilbert 1999). Clustered breeding appears to be more common than previously thought in songbirds (Ahlering and Faaborg 2006) and has recently been documented in congeneric Hooded Warblers (Setophaga citrina; Melles et al. 2009). Interestingly, the latter study found spatial clustering of nests at scales highly similar to those of the present study (240-420 m).

WIWA have been declining for decades (-2.1\% annually since 1966), not only as a whole, but also in the eastern and Québec Breeding Bird Survey (BBS) regions (-2.3\% and $-5.0 \%$ respectively; Sauer et al. 2011). BBS estimates for WIWA may be questionable given that most of them breed north of most BBS routes. However, none of the trends shown here were classified as having deficiencies because of low sample sizes, and each trend shown here was significantly different from zero (with $\alpha=0.05$ ). Given the continued large-scale forest management in boreal eastern Canada (Imbeau et al. 2001), the frequent use of large clear-cuts by breeding WIWA is inconsistent with the idea that habitat loss in the breeding ground would be responsible for the decline of the species. Furthermore, boreal forest management does not usually impact riparian alder, and much of the species' breeding range occurs north of the northern edge of managed forests. In the much less expansive wintering grounds of Central America, WIWA occur in a variety of habitats (Ammon and Gilbert 1999) but prefer mature (Graham and Blake 2001) and moist tropical forests (Lynch 1989) in areas where its habitat use has been studied in detail. Thus, it is likely that phenomena occurring in Central America, such as forest habitat loss (Achard et al. 2002), play a major role in the species' decline, as appears to be the case for other parulid species (Rappole and McDonald 1994, Rappole et al. 2003). Additionally, high mortality during migration as found in other parulids (Sillett and Holmes 2002), may contribute to the long-term dynamics of WIWA.

Modeling songbird habitat use has become a highly sophisticated exercise, with recent advances allowing ways to disentangle detection problems from measures of habitat use or occupancy by a species (Mazerolle et al. 2005, MacKenzie et al. 2006). Songbirds often leave their territories (Kleven et al. 2006, Churchill and Hannon 2010), thus violations of the closure assumption, namely that occupancy remains unchanged throughout the sampling period (MacKenzie et al. 2006, Kendall and White 2009) were likely in this study. However, on the other hand, our results based on logistic regression probably suffered from imperfect detection. Occupancy modeling and mixed-model approaches both have caveats, and may lead to very different results. Thus, as long as the distinction between availability and detectability remains unresolved, those two approaches may provide complementary information on a species' distribution among habitats and bounds for parameter estimates, when detectability is high. In the present study, we were fortunate enough to obtain similar results from logistic and occupancy methods, thus adding strength to our inferences.

\section{CONCLUSION}

Together, our results suggest that clear-cuts and alder patches, especially large ones, offer comparable opportunities for breeding WIWA. Our results are not consistent with the idea that clear-cutting in the boreal forest is a cause for the decline in WIWA populations. Of course, we need similar work in other parts of the northern boreal end of the species' range, as well as information on reproductive success in clear-cut 
habitats, to further evaluate the impact of clear-cutting. Ongoing work at the Forêt Montmorency (A. Corbani, unpublished data) suggests that nesting success of songbirds in recent clear-cuts is as high as elsewhere in the landscape. The present state of knowledge indicates that work on the winter habitat and migration itineraries of the species may be more likely to provide explanations for the species' decline.

Responses to this article can be read online at: http://www.ace-eco.org/vol7/iss2/artl/responses/

\section{Acknowledgments:}

We thank J. Bourque, M.-H. Dickey, and A. Lalis for help in collecting data in the field. We thank anonymous reviewers for their insightful comments on previous drafts of the manuscript. All Forêt Montmorency staff provided great support for site access and logistics of field work. This work was conducted with banding permit \# 10620 (Canadian Wildlife Service) and was funded by FQRNT (Quebec) and NSERC (Canada).

\section{LITERATURE CITED}

Achard, F., H. D. Eva, H.-J. Stibig, P. Mayaux, J. Gallego, T. Richards, and J.-P. Malingreau. 2002. Determination of deforestation rates of the world's humid tropical forests. Science 297:999-1002. http://dx.doi.org/10.1126/science.1070656

Ahlering, M. A., and J. Faaborg. 2006. Avian habitat management meets conspecific attraction: if you build it, will they come? Auk 123:301-312. http://dx.doi.org/10.1642/0004 -8038(2006)123[301:AHMMCA]2.0.CO;2

Ammon, E. M., and W. M. Gilbert. 1999. Wilson's Warbler (Cardellina pusilla). In A. Poole, editor. The birds of North America online. Cornell Lab of Ornithology, Ithaca, New York, USA. [online] URL: http://bna.birds.cornell.edu/bna/sp ecies/478

Beauchesne, P., P. Larue, L. Bélanger, and J. Huot. 1991. Effets de coupes de dimensions restreintes sur l'abondance des populations d'oiseaux nicheurs en milieu boréal. Forestry Chronicle 67:397-402.

Boucher, Y., D. Arseneault, L. Sirois, and L. Blais. 2009. Logging pattern and landscape changes over the last century at the boreal and deciduous forest transition in Eastern Canada. Landscape Ecology 24:171-184. http://dx.doi.org/10.1007/s1 $\underline{0980-008-9294-8}$

Bourque, J., and A. Desrochers. 2006. Spatial aggregation of forest songbird territories and possible implications for areasensitivity. Avian Conservation and Ecology 1(2): 3. [online] URL: http://www.ace-eco.org/vol1/iss2/art3/
Brooks, R. T. 2003. Abundance, distribution, trends, and ownership patterns of early-successional forests in the northeastern United States. Forest Ecology and Management 185:65-74. http://dx.doi.org/10.1016/S0378-1127(03)00246-9

Burnham, K. P., and D. R. Anderson. 2002. Model selection and inference: a practical information-theoretic approach. Second edition. Springer-Verlag, New York, New York, USA.

Churchill, J. L., and S. J. Hannon. 2010. Off-territory movement of male American Redstarts (Setophaga ruticilla) in a fragmented agricultural landscape is related to song rate, mating status and access to females. Journal of Ornithology 151:33-44. http://dx.doi.org/10.1007/s10336-009-0419-x

Clegg, S. M., J. F. Kelly, M. Kimura, and T. B. Smith. 2003. Combining genetic markers and stable isotopes to reveal population connectivity and migration patterns in a Neotropical migrant, Wilson's warbler (Wilsonia pusilla). Molecular Ecology 12:819-830. http://dx.doi.org/10.1046/j.1 $\underline{365-294 X .2003 .01757 . x}$

Courteau, M. 2000. Évaluation de l'hétérogénéité des coupes forestières à l'aide d'outils géomatiques. Thesis. Université Laval, Québec, Québec, Canada.

Crête, M., B. Drolet, J. Huot, M.-J. Fortin, and G. J. Doucet. 1995. Chronoséquence après feu de la diversité de mammifères et d'oiseaux au nord de la forêt boréale québécoise. Canadian Journal of Forest Research 25:1509-1518. http://dx.doi.org/10.1139/x95-164

de Bellefeuille, S., L. Bélanger, J. Huot, and A. Cimon. 2001. Clear-cutting and regeneration practices in Quebec boreal balsam fir forest: effects on snowshoe hare. Canadian Journal of Forest Research 31:41-51. http://dx.doi.org/10.1139/x00-140

Desrochers, A., C. Renaud, W. M. Hochachka, and M. Cadman. 2010. Area-sensitivity by forest songbirds: theoretical and practical implications of scale-dependency. Ecography 33:921-931. http://dx.doi.org/10.1111/j.1600-058 7.2009.06061.x

Drapeau, P., A. Leduc, J.-F. Giroux, J.-P. L. Savard, Y. Bergeron, and W. L. Vickery. 2000. Landscape-scale disturbances and changes in bird communities of boreal mixed-wood forests. Ecological Monographs 70:423-444. http://dx.doi.org/10.1890/0012-9615(2000)070[0423:LSDACI] 2.0.CO 2

Environmental Systems Research Institute (ESRI). 2008. $\operatorname{ArcGIS}^{\circledast}$ 9.3. ESRI Inc., Redlands, California, USA. 
Fiske, I., R. B. Chandler, and A. Royle. 2011. Unmarked: models for data from unmarked animals. $\mathrm{R}$ package version 0.9-0. [online] URL: http://CRAN.R-project.org/package=un marked

Fretwell, S. D. 1972. Populations in a seasonal environment. Princeton University Press, Princeton, New Jersey, USA.

Gauthier, J., and Y. Aubry, editors. 1996. The breeding birds of Québec: atlas of the breeding birds of southern Québec. Association Québécoise des Groupes d'Ornithologues, Province of Québec Society for the Protection of Birds, Canadian Wildlife Service, Environnement Canada (Québec region), Montréal, Québec, Canada.

Graham, C. H., and J. G. Blake. 2001. Influence of patch- and landscape-level factors on bird assemblages in a fragmented tropical landscape. Ecological Applications 11:1709-1721. http://dx.doi.org/10.1890/1051-0761(2001)011[1709:IOPALL] 2.0.CO;2

Hejl, S. J., R. L. Hutto, C. R. Preston, and D. M. Finch. 1995. Effects of silvicultural treatments in the Rocky Mountains. Pages 220-244 in T. E. Martin and D. M. Finch, editors. Ecology and management of neotropical migratory birds. Oxford University Press, New York, New York, USA.

Hines, J. E. 2006. PRESENCE version 3.1: Software to estimate patch occupancy and related parameters. USGS Patuxent Wildlife Reasearch Center, Laurel, Maryland, USA. [online] URL: http://www.mbr-pwrc.usgs.gov/software/presence. $\underline{\mathrm{html}}$

Hines, J. E., J. D. Nichols, J. A. Royle, D. I. MacKenzie, A. M. Gopalaswamy, N. S. Kumar, and K. U. Karanth. 2010. Tigers on trails: occupancy modeling for cluster sampling. Ecology 20:1456-1466.

Hunter, W. C., D. A. Buehler, R. A. Canterbury, J. L. Confer, and P. B. Hamel. 2001. Conservation of disturbancedependent birds in eastern North America. Wildlife Society Bulletin 29(2):440-455.

Ihaka, R., and R. Gentleman. 1996. R: a language for data analysis and graphics. Journal of Computational and Graphical Statistics 5:299-314.

Imbeau, L., M. Mönkkönen, and A. Desrochers. 2001. Longterm effects of forestry on birds of the eastern Canadian boreal forests: a comparison with Fennoscandia. Conservation Biology 15:1151-1162. http://dx.doi.org/10.1046/j.1523-1739 $.2001 .0150041151 . \mathrm{x}$

Imbeau, L., J.-P. L. Savard, and R. Gagnon. 1999. Comparing bird assemblages in successional black spruce stands originating from fire and logging. Canadian Journal of Zoology 77:1850-1860.

Kendall, W. L., and G. C. White. 2009. A cautionary note on substituting spatial subunits for repeated temporal sampling in studies of site occupancy. Journal of Applied Ecology 46:1182-1188.

Kimura, M., S. M. Clegg, I. J. Lovette, K. R. Holder, D. J. Girman, B. Milá, S. P. Wade, and T. B. Smith. 2002. Phylogeographical approaches to assessing demographic connectivity between breeding and overwintering regions in a neartic-neotropical warbler (Wilsonia pusilla). Molecular Ecology 11:1605-1616. http://dx.doi.org/10.1046/j.1365-294 $\underline{X .2002 .01551 . \mathrm{X}}$

Kleven, O., G. Marthinsen, and J. T. Lifjeld. 2006. Male extraterritorial forays, age and paternity in the socially monogamous Reed Bunting (Emberiza schoeniclus). Journal of Ornithology 147:468-473. http://dx.doi.org/10.1007/s1033 6-005-0039-z

Kokko, H. 1999. Competition for early arrival in migratory birds. Journal of Animal Ecology 68:940-950. http://dx.doi.o rg/10.1046/j.1365-2656.1999.00343.x

Kölliker, M., P. Heeb, I. Werner, A. C. Mateman, C. M. Lessells, and H. Richner. 1999. Offspring sex ratio is related to male body size in the Great Tit (Parus major). Behavioral Ecology 10:68-72. http://dx.doi.org/10.1093/beheco/10.1.68

Lynch, J. F. 1989. Distribution of overwintering nearctic migrants in the Yucatan Peninsula, I: general patterns of occurrence. Condor 91:515-544. http://dx.doi.org/10.2307/13 $\underline{68104}$

MacKenzie, D. I., and L. L. Bailey. 2004. Assessing the fit of site-occupancy models. Journal of Agricultural, Biological, and Environmental Statistics 9:300-318. http://dx.doi.org/10. $\underline{1198 / 108571104 X 3361}$

MacKenzie, D. I., J. D. Nichols, J. E. Hines, M. G. Knutson, and A. B. Franklin. 2003. Estimating site occupancy, colonization, and local extinction when a species is detected imperfectly. Ecology 84:2200-2207. http://dx.doi.org/10.1890 $\underline{102-3090}$

MacKenzie, D. I., J. D. Nichols, J. A. Royle, K. H. Pollock, L. L. Bailey, and J. E. Hines. 2006. Occupancy estimation and modeling: inferring patterns and dynamics of species occurrence. Academic Press, New York, New York, USA.

Mazerolle, M. J. 2011. AICcmodavg: model selection and multimodel inference based on $(Q) A I C(c)$. R package version 1.16. [online] URL: http://CRAN.R-project.org/package=AIC cmodavg

Mazerolle, M. J., A. Desrochers, and L. Rochefort. 2005. Landscape characteristics influence pond occupancy by frogs after accounting for detectability. Ecological Applications 15:824-834. http://dx.doi.org/10.1890/04-0502

Melles, S. J., D. Badzinski, M.-J. Fortin, F. Csillag, and K. Lindsay. 2009. Disentangling habitat and social drivers of 
nesting patterns in songbirds. Landscape Ecology 24:519-531. http://dx.doi.org/10.1007/s10980-009-9329-9

Morris, D. W. 1989. Density-dependent habitat selection: testing the theory with fitness data. Evolutionary Ecology 3:80-94. http://dx.doi.org/10.1007/BF02147934

Nocera, J. J., G. J. Forbes, and L.-A. Giraldeau. 2009. Aggregations from using inadvertent social information: a form of ideal habitat selection. Ecography 32:143-152. http:// dx.doi.org/10.1111/j.1600-0587.2008.05614.x

Pothier, D., M. Prévost, and I. Auger. 2003. Using the shelterwood method to mitigate water table rise after forest harvesting. Forest Ecology and Management 179:573-583. http://dx.doi.org/10.1016/S0378-1127(02)00530-3

Pyle, P. 1997. Identification guide to North American birds, Part I. Slate Creek Press, Bolinas, California, USA.

Rappole, J. H., D. I. King, and J. Diez. 2003. Winter- vs. breeding-habitat limitation for an endangered avian migrant. Ecological Applications 13:735-742. http://dx.doi.org/10.189 0/1051-0761(2003)013[0735:WVBLFA]2.0.CO;2

Rappole, J. H., and M. V. McDonald. 1994. Cause and effect in population declines of migratory birds. Auk 111:652-660.

Rohwer, S. 1975. The social significance of avian winter plumage variability. Evolution 29:593-610. http://dx.doi.org/ $\underline{10.2307 / 2407071}$

SAS Institute. 2009. SAS software. Version 9.2. SAS Institute Inc., Cary, North Carolina, USA.

Sauer, J. R., J. E. Hines, J. E. Fallon, K. L. Pardieck, J. D. J. Ziolkowski, and W. A. Link. 2011. The North American breeding bird survey, results and analysis 1966 - 2010. Version 12.07.2011. USGS Patuxent Wildlife Research Center, Laurel, Maryland, USA.

Schaalje, G. B., J. B. McBride, and G. W. Fellingham. 2001. Approximations to distributions of test statistics in complex mixed linear models using SAS ${ }^{\circledR}$ Proc MIXED. Pages 262-226 in Proceedings of the SAS Users Group International 26th Annual Conference. SAS Institute Inc., Cary, North Carolina, USA

Schlossberg, S., and D. I. King. 2009. Postlogging succession and habitat usage of shrubland birds. Journal of Wildlife Management 73:226-231. http://dx.doi.org/10.2193/2007-518

Sillett, T. S., and R. T. Holmes. 2002. Variation in survivorship of a migratory songbird throughout its annual cycle. Journal of Animal Ecology 71:296-308. http://dx.doi.org/10.1046/j.13 65-2656.2002.00599.x

Simon, N. P. P., F. E. Schwab, and R. D. Otto. 2002. Songbird abundance in clear-cut and burned stands: a comparison of natural disturbance and forest management. Canadian Journal of Forest Research 32:1343-1350. http://dx.doi.org/10.1139/x $\underline{02-057}$

Thusius, K. J., K. A. Peterson, P. O. Dunn, and L. A. Whittingham. 2001. Male mask size is correlated with mating success in the Common Yellowthroat. Animal Behaviour 62:435-446. http://dx.doi.org/10.1006/anbe.2001.1758

Whitaker, D. M., and I. G. Warkentin. 2010. Spatial ecology of migratory passerines on temperate and boreal forest breeding grounds. Auk 127:471-484. http://dx.doi.org/10.1525/ auk.2010.127.3.471

Zuckerberg, B., A. Desrochers, W. M. Hochachka, D. Fink, W. D. Koenig, and J. L. Dickinson. 2012. Overlapping landscapes: a persistent, but misdirected concern when collecting and analyzing ecological data. Journal of Wildlife Management 76(5):1072-1080. http://dx.doi.org/10.1002/jwm g. 326 